\title{
Cadmium Complexed with $\beta 2-$ Microglubulin, Albumin and Lipocalin-2 rather than Metallothionein Cause Megalin:Cubilin Dependent Toxicity of the Renal Proximal Tubule
}

\author{
Johannes Fels ${ }^{1,+}+{ }^{\circ}$, Bettina Scharner ${ }^{1,+}$, Ralf Zarbock ${ }^{1}$, Itzel Pamela Zavala Guevara ${ }^{2}$, \\ Wing-Kee Lee ${ }^{1}\left(\mathbb{D}\right.$, Olivier C. Barbier ${ }^{2}$ (D) and Frank Thévenod ${ }^{1, *(D)}$ \\ 1 Department of Physiology, Pathophysiology \& Toxicology and ZBAF (Centre for Biomedical Education and \\ Research), Faculty of Health, School of Medicine, Witten/Herdecke University, D-58453 Witten, Germany; \\ Johannes.Fels@uni-wh.de (J.F.); Bettina.Scharner@uni-wh.de (B.S.); Ralf.Zarbock@uni-wh.de (R.Z.); \\ Wing-Kee.Lee@uni-wh.de (W.-K.L.) \\ 2 Departamento de Toxicología, Centro de Investigación y de Estudios Avanzados del Instituto Politécnico \\ Nacional (CINVESTAV-IPN), Mexico 07360, México; pamela0191@hotmail.com (I.P.Z.G.); \\ obarbier@cinvestav.mx (O.C.B.) \\ * Correspondence: frank.thevenod@uni-wh.de; Tel.: +49-(0)2302-926-221 \\ + These authors contributed equally to this work.
}

Received: 31 March 2019; Accepted: 9 May 2019; Published: 14 May 2019

\begin{abstract}
Cadmium $\left(\mathrm{Cd}^{2+}\right)$ in the environment is a significant health hazard. Chronic low $\mathrm{Cd}^{2+}$ exposure mainly results from food and tobacco smoking and causes kidney damage, predominantly in the proximal tubule. Blood $\mathrm{Cd}^{2+}$ binds to thiol-containing high (e.g., albumin, transferrin) and low molecular weight proteins (e.g., the high-affinity metal-binding protein metallothionein, $\beta 2$-microglobulin, $\alpha 1$-microglobulin and lipocalin-2). These plasma proteins reach the glomerular filtrate and are endocytosed at the proximal tubule via the multiligand receptor complex megalin:cubilin. The current dogma of chronic $\mathrm{Cd}^{2+}$ nephrotoxicity claims that $\mathrm{Cd}^{2+}$-metallothionein endocytosed via megalin:cubilin causes renal damage. However, a thorough study of the literature strongly argues for revision of this model for various reasons, mainly: (i) It relied on studies with unusually high $\mathrm{Cd}^{2+}$-metallothionein concentrations; (ii) the $K_{D}$ of megalin for metallothionein is $\sim 10^{5}$-times higher than $\left(\mathrm{Cd}^{2+}\right)$-metallothionein plasma concentrations. Here we investigated the uptake and toxicity of ultrafiltrated $\mathrm{Cd}^{2+}$-binding protein ligands that are endocytosed via megalin:cubilin in the proximal tubule. Metallothionein, $\beta 2$-microglobulin, $\alpha 1$-microglobulin, lipocalin-2, albumin and transferrin were investigated, both as apo- and $\mathrm{Cd}^{2+}$-protein complexes, in a rat proximal tubule cell line (WKPT-0293 Cl.2) expressing megalin:cubilin at low passage, but is lost at high passage. Uptake was determined by fluorescence microscopy and toxicity by MTT cell viability assay. Apo-proteins in low and high passage cells as well as $\mathrm{Cd}^{2+}$-protein complexes in megalin:cubilin deficient high passage cells did not affect cell viability. The data prove $\mathrm{Cd}^{2+}$-metallothionein is not toxic, even at $>100$-fold physiological metallothionein concentrations in the primary filtrate. Rather, $\mathrm{Cd}^{2+}-\beta 2$-microglobulin, $\mathrm{Cd}^{2+}$-albumin and $\mathrm{Cd}^{2+}$-lipocalin-2 at concentrations present in the primary filtrate are taken up by low passage proximal tubule cells and cause toxicity. They are therefore likely candidates of $\mathrm{Cd}^{2+}$-protein complexes damaging the proximal tubule via megalin:cubilin at concentrations found in the ultrafiltrate.
\end{abstract}

Keywords: Cadmium nephrotoxicity; proximal tubule; megalin; cubilin; metallothionein; albumin; transferrin; $\beta 2$-microglobulin; lipocalin-2 


\section{Introduction}

Cadmium $\left(\mathrm{Cd}^{2+}\right)$ pollution is increasing in the environment worldwide due to industrial activities and because it cannot be further degraded. Compared to other transition metals, $\mathrm{Cd}^{2+}$ and $\mathrm{Cd}^{2+}$ compounds are relatively water soluble, more bio-available, and therefore tend to bio-accumulate [1] Chronic $\mathrm{Cd}^{2+}$ exposure, mainly from contaminated dietary sources and cigarette smoking [2], leads to $\mathrm{Cd}^{2+}$ accumulation in the human body, especially in the kidneys where renal tubular damage is probably the most critical health effect.

Following absorption in the intestine and/or lungs, $\mathrm{Cd}^{2+}$ in the blood initially binds largely to albumin and other thiol-containing high-molecular (HMWP) and low-molecular weight proteins (LMWP) in the plasma, including metallothioneins (MT), as well as to blood cells [2]. MT, a cysteine-rich metal-binding protein, binds both physiological $\mathrm{Zn}^{2+}$ ions and toxic $\mathrm{Cd}^{2+}$ ions through the thiol group of its cysteine residues with very high affinity $\left(K_{D}\right.$ for $\left.\mathrm{Cd}^{2+} \sim 10^{-14} \mathrm{~mol} / \mathrm{L}\right)[3]$.

In the literature, a presumed model prevails wherein blood $\mathrm{Cd}^{2+}$ is taken up by hepatocytes [4] or Kupffer cells [5] in which free cytosolic $\mathrm{Cd}^{2+}$ is thought to induce synthesis of MT to bind and detoxify $\mathrm{Cd}^{2+}$. Supposedly, $\mathrm{Cd}^{2+}-\mathrm{MT}$ is steadily released into the bloodstream as the cells undergo necrosis, either through normal cell turnover or as a result of $\mathrm{Cd}^{2+}$ injury, and redistributes to the kidney. Since intravenously injected $\mathrm{Cd}^{2+}-\mathrm{MT}$ in mice is quickly cleared from the plasma by the kidneys [6], this protein fraction in the circulation is thought to be of great importance for $\mathrm{Cd}^{2+}$ shuttling from the liver to the kidney during long-term exposure [7-9]. Although some experimental evidence exists from animal studies that $\mathrm{Cd}^{2+}$ redistributes from the liver to the kidney during chronic exposure to high $\mathrm{Cd}^{2+}$ concentrations, this is not the case for low environmentally relevant blood concentrations [9], which in humans range between 0.03 and $0.5 \mu \mathrm{g} / \mathrm{L}(\sim 0.3-5 \mathrm{nmol} / \mathrm{L})$ (reviewed in reference [10]). In fact, the plasma $\mathrm{Cd}^{2+}$-MT concentrations following intravenous injections exceeded physiological MT concentrations by $>2000$-fold [11,12]. With a molecular mass (MM) of $\sim 3.5-14 \mathrm{kDa},\left(\mathrm{Cd}^{2+}\right)-\mathrm{MT}$ easily crosses the glomerular barrier (cut-off $\sim 80 \mathrm{kDa}$ ) and is thought to be completely endocytosed from the ultrafiltrate in the S1-segment of the proximal tubule (PT) $[13,14]$, by the multiligand, endocytic-membrane receptor complex megalin:cubilin [15]. Endocytosed $\mathrm{Cd}^{2+}-\mathrm{MT}$ is trafficked to acidic late endosomes and lysosomes where the protein moiety is degraded and $\mathrm{Cd}^{2+}$ is extruded via divalent metal transporter 1 (DMT1) into the cytosol to develop toxicity [16].

Megalin:cubilin also binds and retrieves other filtered proteins, such as the LMWP $\beta 2$-microglobulin ( $\beta 2 \mathrm{M} ; \mathrm{MM} \sim 11 \mathrm{kDa}$ ) neutrophil gelatinase-associated lipocalin (NGAL)/lipocalin-2 (Lcn2; MM 22-25 $\mathrm{kDa}$ ), and $\alpha 1$-microglobulin ( $\alpha 1 \mathrm{M} ; \mathrm{MM} \sim 27 \mathrm{kDa}$ ), as well as the HMWP albumin (Alb; MM $\sim 67 \mathrm{kDa}$ ) and transferrin (Tf; MM $\sim 76 \mathrm{kDa}$ ) (reviewed in reference [15]). In contrast to LMWP, which are freely filtered and are present in similar concentrations in plasma and ultrafiltrate, only lower concentrations of HMWP will be found in the ultrafiltrate based on their estimated glomerular sieving coefficients (reviewed in reference [17]). Furthermore, the aforementioned proteins also bind divalent metal ions, including $\mathrm{Cd}^{2+}$, with $K_{D}$ values of $\sim 10^{-6} \mathrm{~mol} / \mathrm{L}$ and maximally two binding sites [18-20].

Hence, megalin:cubilin represents a high-capacity receptor for endocytosis that prevents protein loss from the body into the urine [21]. Although the affinity of megalin:cubilin to most of its protein ligands is high $\left(K_{D}\right.$ varies between $\left.20-600 \mathrm{nmol} / \mathrm{L}\right)$ (reviewed in reference [17]), its affinity to MT is in the high micromolar range [22,23], which practically excludes MT uptake by the PT, taking into account that plasma (and ultrafiltrate) concentrations of MT measured are in the high picomolar to low nanomolar range $[11,12]$. This has been overlooked in the literature so far and indicates that $\mathrm{Cd}^{2+}-\mathrm{MT}$ is not the primary source of complexed $\mathrm{Cd}^{2+}$ responsible for damaging the kidney PT.

In the present study we have determined the uptake and toxicity of $\mathrm{Cd}^{2+}$ complexed to LMWP $\beta 2 \mathrm{M}, \alpha 1 \mathrm{M}$ and Lcn2 and the HMWP Alb and Tf using a rat PT cell line (WKPT-0293 Cl.2) expressing megalin:cubilin. The data reiterate that $\mathrm{Cd}^{2+}-\mathrm{MT}$ is not toxic, even at concentrations that exceed the physiological MT concentrations in the ultrafiltrate by $\sim 100$-fold. Rather, $\mathrm{Cd}^{2+}-\beta 2 \mathrm{M}, \mathrm{Cd}^{2+}-\mathrm{Alb}$ and $\mathrm{Cd}^{2+}-\mathrm{Lcn} 2$ are taken up by PT cells and cause toxicity at ultrafiltrate concentrations and therefore 
represent more likely candidates of $\mathrm{Cd}^{2+}$-protein complexes that damage the renal PT via megalin:cubilindependent endocytosis.

\section{Results}

The WKPT-0293 Cl.2 cell line, derived from the S1-segment of rat PT [24], is one of few renal PT cell lines to express megalin and cubilin (Figure 1) [23,25,26], which is lost at passage numbers exceeding 40. Real-time PCR confirmed loss of megalin mRNA in high passage $(p>100)$ compared to low passage ( $p \leq 40$ cells) (Figure 1A). Importantly, low passage cells also express higher cubilin (Cubn) mRNA levels than high passage cells (Figure 1A) since endocytosis of Tf, Alb and $\alpha 1 \mathrm{M}$ requires cubilin binding and interaction with megalin to occur [27-29] (reviewed in reference [15]). In contrast, endocytosis of MT, Lcn 2 and $\beta 2 \mathrm{M}$ is exclusively megalin-dependent. Interestingly, mRNA expression levels of megalin were higher than cubilin in low passage cells (Figure 1A), which is in agreement with their relative protein expression in rat PT [21]. Immunofluorescence staining using a commercial monoclonal antibody against whole megalin whose epitope has not yet been characterized (courtesy of Novus Biologicals) clearly shows staining in permeabilized low passage, but not in high passage cells (Figure 1B,C). No positive staining was detected in non-permeabilized low passage cells, which indicates that the antibody is directed against an intracellular epitope. Immunoblotting of cubilin in low and high passage cells (Figure 1D) confirmed cubilin protein expression in low, but not in high passage cells.

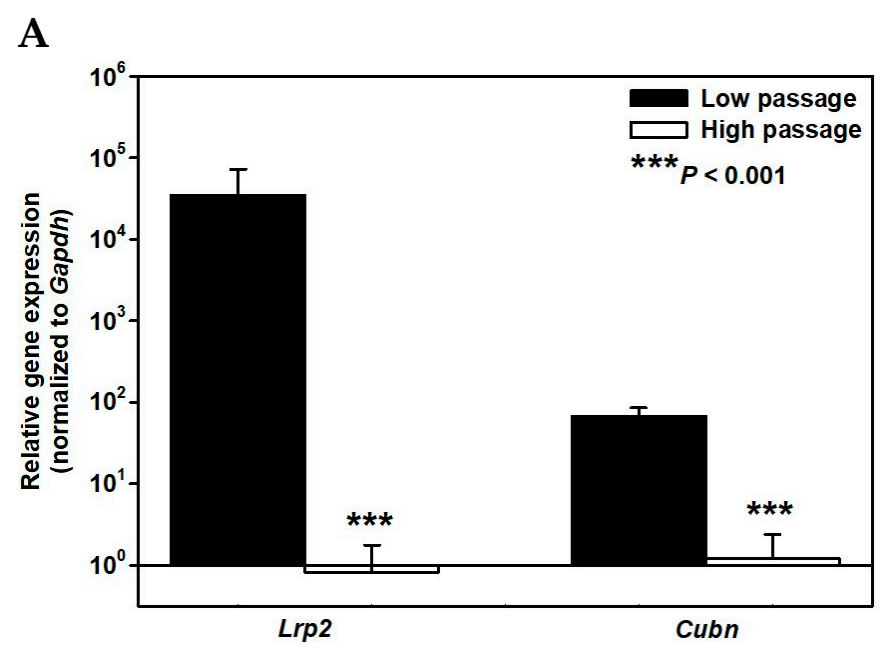

B

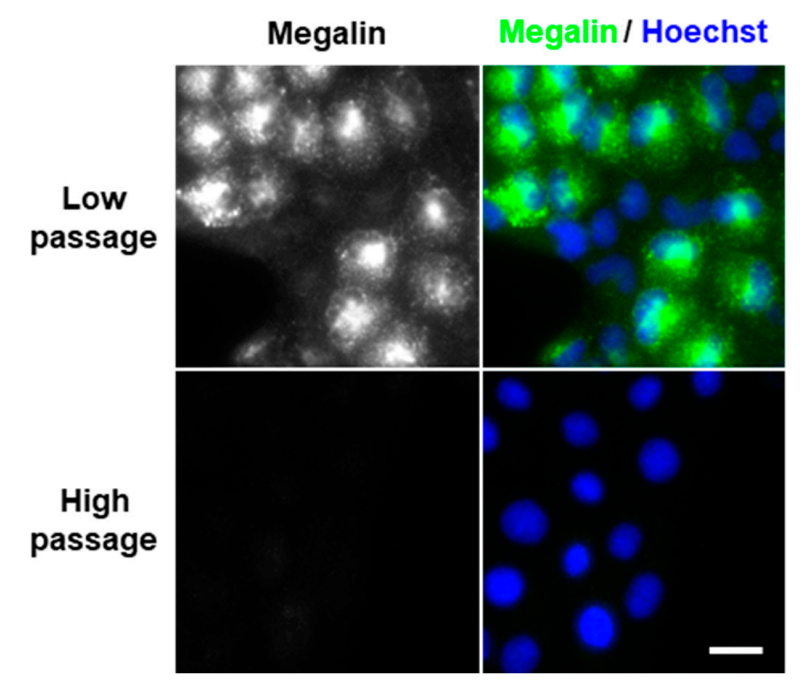

Figure 1. Cont. 


\section{C}

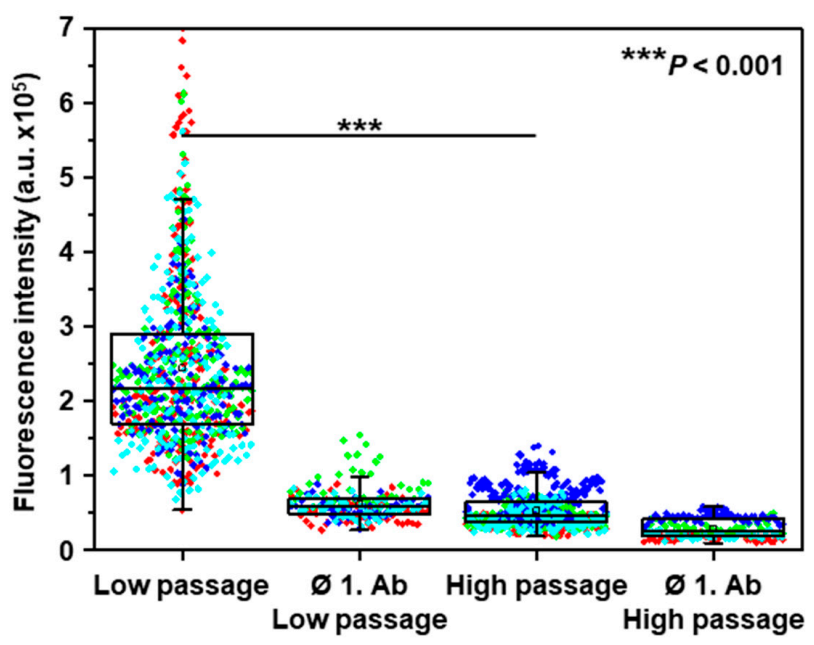

D

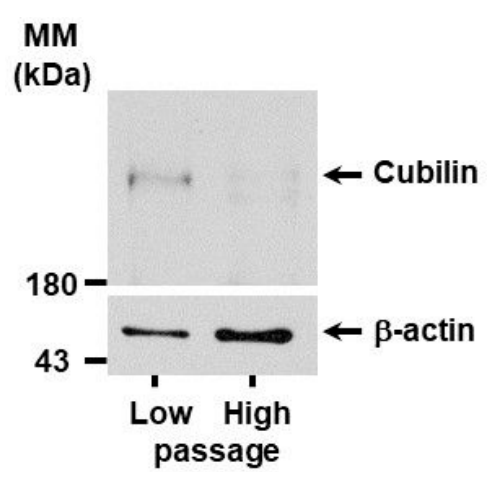

Figure 1. Expression of megalin and cubilin in cultured low and high passage rat renal proximal tubule cells (WKPT-0293 C1.2). (A) Expression levels of megalin (Lrp2) and cubilin (Cubn) mRNA by qPCR in means \pm SD of 4 experiments are shown. The $C_{T}$ values in low passage cells were $20.6 \pm 0.6$ and $29.6 \pm 0.1$ for megalin and cubilin, respectively. Data obtained were normalized to the expression of the reference gene glyceraldehyde-3-phosphate dehydrogenase (Gapdh). Statistical analysis compares the low and high passage cells by unpaired $t$-test. (B) Expression of megalin protein in low and high passage WKPT-0293 Cl.2 cells. Megalin was detected by immunofluorescence microscopy of permeabilized cells (green). Nuclei were counterstained with Hoechst 33342 (blue). The experiment is representative of four similar ones. Scale bar $=20 \mu \mathrm{m}$. (C) Fluorescence intensity was analyzed in 188-705 cells (dots) from 4 different experiments (colors); for details of box and whisker plot statistics, see Section 4. Statistical analysis compares the low and high passage cells by non-parametric one-way ANOVA (Kruskal-Wallis-Test, using Dunn's post-hoc analysis). (D) Expression of cubilin protein was detected by immunoblotting. $\beta$-actin was used as loading control. A representative experiment is shown. $\mathrm{MM}=$ molecular mass.

MT has been demonstrated to be a low affinity ligand of megalin in previous studies by surface plasmon resonance [22] or uptake of Alexa Fluor 488-coupled MT in WKPT-0293 C1.2 cells [23]. As shown in Figure 2A, $\mathrm{Cd}^{2+}-\mathrm{MT}$ toxicity increased as a function of concentration in low passage cells but became only significantly different to high passage cells at the highest tested concentration of $10 \mu \mathrm{mol} / \mathrm{L} \mathrm{Cd}^{2+}-\mathrm{MT}\left(\cong 70 \mu \mathrm{mol} / \mathrm{L} \mathrm{Cd}^{2+}\right.$ ) after $24 \mathrm{~h}$ exposure. In contrast, high passage cells did not show significant toxicity at all concentrations tested, further demonstrating the importance of megalin for $\mathrm{Cd}^{2+}$-MT endocytosis. Similarly, a high concentration of $7.14 \mu \mathrm{mol} / \mathrm{L} \mathrm{Cd}^{2+}-\mathrm{MT}\left(\cong 50 \mu \mathrm{mol} / \mathrm{L} \mathrm{Cd}^{2+}\right)$, which was used in WKPT-0293 Cl.2 cells in previous studies [23], showed $59 \pm 4 \%$ cell viability $(n=5 ; p<0.01)$ in low passage cells expressing megalin and $98 \pm 13 \%$ cell viability in megalin-deficient 
high passage cells $(n=4 ; p<0.01)$ whereas no difference was observed for MT alone (Figure 2B). In contrast, $50 \mu \mathrm{mol} / \mathrm{L} \mathrm{CdCl}_{2}(24 \mathrm{~h})$ decreased cell viability to $\%(n=4)$ in both high and low passage cells, indicating that the mechanisms of $\mathrm{CdCl}_{2}$ toxicity differ from $\mathrm{Cd}^{2+}-\mathrm{MT}$ toxicity and also proving that the totality of excess free $\mathrm{Cd}^{2+}$ has been removed from $\mathrm{Cd}^{2+}-\mathrm{MT}$ (see Section 4.2).
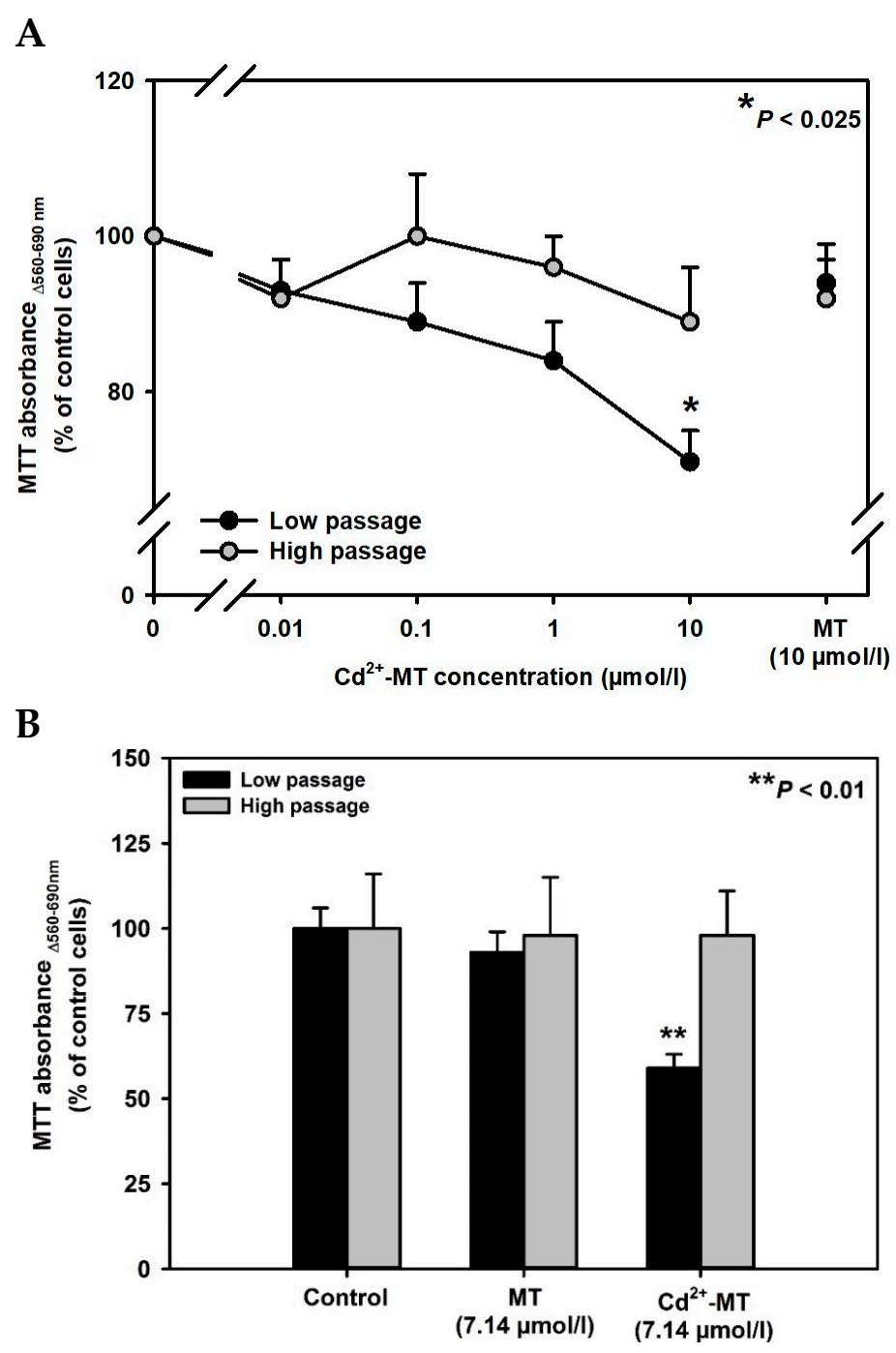

Figure 2. Low affinity of $\mathrm{Cd}^{2+}-\mathrm{MT}$ to megalin:cubilin in low passage WKPT-0293 Cl.2 cells. Treatments were performed in $\mathrm{SFM}_{\text {mod, }}$ and cell viability was assessed using MTT assay. (A) Low and high passage cells were exposed to different concentrations of $\mathrm{Cd}^{2+}-\mathrm{MT}$ for $24 \mathrm{~h}$. Means \pm SEM of 8-11 experiments are shown. Absorbance values of control cells (modified serum-free medium only were $0.41 \pm 0.16 \mathrm{a}$. $\mathrm{u}$. $(n=11)$ and $0.51 \pm 0.19$ a.u. $(n=8))$ for low and high passage cells, respectively, were set to $100 \%$, and different $\mathrm{Cd}^{2+}$-MT concentrations were normalized accordingly. (B) Low and high passage cells were exposed to $7.14 \mu \mathrm{mol} / \mathrm{L} \mathrm{MT}$ or $\mathrm{Cd}^{2+}-\mathrm{MT}(\cong 50 \mu \mathrm{mol} / \mathrm{L}$ for $24 \mathrm{~h})$. Means $\pm \mathrm{SEM}$ of $4-5$ experiments are shown. Absorbance values of control cells were $1.06 \pm 0.07$ a.u. $(n=5)$ and $0.86 \pm 0.14$ a.u. $(n=4)$ for low and high passage cells, respectively, and set to $100 \%$. Statistical analyses compared low to high passage cells by unpaired $t$-test.

Since in vivo relevant concentrations of $\mathrm{Cd}^{2+}-\mathrm{MT}$ in plasma [11,12] and primary filtrate, which are in the low nanomolar range (Table 1), are unlikely to cause PT toxicity because megalin:cubilin affinity for MT is too low, alternative candidate $\mathrm{Cd}^{2+}$-protein ligands for megalin:cubilin were investigated, i.e., $\beta 2 \mathrm{M}, \mathrm{Lcn} 2, \mathrm{Tf}, \mathrm{Alb}$ and $\alpha 1 \mathrm{M}[15,17]$. Similarly to MT, the concentration of the cubilin ligand $\mathrm{Tf}$ in the primary filtrate is in the low nanomolar range at $2 \mathrm{nmol} / \mathrm{L}$ and binds megalin with high affinity 
(Table 1). In contrast, $\beta 2 \mathrm{M}, \mathrm{Alb}$ and $\alpha 1 \mathrm{M}$ are present in the primary filtrate at $\sim 100,50$ and $92 \mathrm{nmol} / \mathrm{L}$, respectively (Table 1 ). Whereas $\beta 2 \mathrm{M}$ and Alb have known $K_{D}$ for megalin and cubilin, respectively, at high nanomolar concentrations (Table 1), the $K_{D}$ of $\alpha 1 \mathrm{M}$ for cubilin is unknown [15]. Finally, Lcn2 has a higher expected primary filtrate concentration of $\sim 650 \mathrm{nmol} / \mathrm{L}$ and a $K_{D}$ for megalin binding that is similar to Tf (see Table 1).

To mimic the $\mathrm{Cd}^{2+}$-protein concentrations measured in the filtrate (to which PT cells are exposed to), low passage cells were also incubated for $24 \mathrm{~h}$ with $100 \mathrm{nmol} / \mathrm{L}$ of $\beta 2 \mathrm{M}$, and $\mathrm{Alb}$ or $\alpha 1 \mathrm{M}$ as apo-proteins or as $\mathrm{Cd}^{2+}$ complexes, and MTT absorbance was measured (Figure 3A). MT at the same concentration was included for comparison. Similarly as shown in Figure $2 \mathrm{~A}, \mathrm{Cd}^{2+}-\mathrm{MT}$ was not toxic (although its filtrate concentration is $\sim 100$-fold lower). In contrast, $\mathrm{Cd}^{2+}-\beta 2 \mathrm{M}$ significantly decreased cell viability ( $59 \pm 6 \% ; n=4$; Figure $3 \mathrm{~A})$. A concentration of $\mathrm{Tf}$ at the approximately expected filtrate concentration ( $5 \mathrm{nmol} / \mathrm{L} \mathrm{Cd}^{2+}$-Tf with $10 \mathrm{nmol} / \mathrm{L} \mathrm{Cd}^{2+}$ assuming $2 \mathrm{Cd}^{2+}$-binding sites [18]) did not reduce cell viability of low passage WKPT-0293 Cl.2 cells. Even at $100 \mathrm{nmol} / \mathrm{L} \mathrm{Cd}^{2+}-\mathrm{Tf}$ showed no significant decrease of cell viability ( $90 \pm 13 \%$ cell viability; $n=8)$, indicating that it is not likely to cause toxicity in vivo. Interestingly, $\mathrm{Cd}^{2+}$-Alb (assuming $1 \mathrm{Cd}^{2+}$-binding site [19]) significantly decreased cell viability ( $59 \pm 8 \% ; n=7$; Figure $3 \mathrm{~A}$ ). Yet $100 \mathrm{nmol} / \mathrm{L} \mathrm{Cd}^{2+}-\alpha 1 \mathrm{M}$ did not induce significant toxicity in low passage cells $(82 \pm 14 \%$ cell viability; $n=9)$. At $100 \mathrm{nmol} / \mathrm{L}, \mathrm{Cd}^{2+}-\mathrm{Lcn} 2$ was not toxic $(103 \pm 7 \%$ of cell viability; $n=5$; Figure $3 \mathrm{~B})$. However, $\mathrm{Cd}^{2+}-\mathrm{Lcn} 2$ at $1 \mu \mathrm{mol} / \mathrm{L}$, a concentration close to that in the primary filtrate (Table 1 ) also showed significant toxicity in low passage cells $(64 \pm 4 \% ; n=6$; Figure 3B).Viability of high passage cells was unaffected by $\mathrm{Cd}^{2+}-\beta 2 \mathrm{M}, \mathrm{Cd}^{2+}-\mathrm{Alb}$ or $\mathrm{Cd}^{2+}-\mathrm{Lcn} 2$, when tested under the same conditions.

Table 1. Binding affinities and estimated concentrations of ligands of megalin and cubilin in the renal glomerular filtrate.

\begin{tabular}{llccc}
\hline \multicolumn{1}{c}{ Ligand } & Receptor & $\boldsymbol{K}_{\boldsymbol{D}}(\mathbf{n m o l} / \mathbf{L})$ & Reference & Concentration in Glomerular Filtrate $(\mathbf{n m o l} / \mathbf{L})$ \\
\hline MT & Megalin & 100,000 & {$[22]$} & $0.5-5$ \\
$\boldsymbol{\beta} \mathbf{2 M}$ & Megalin & 420 & {$[30]$} & 100 \\
Lcn2 & Megalin & 60 & {$[31]$} & 650 \\
Tf & Cubilin & 20 & {$[27]$} & 2 \\
Alb & Cubilin & 630 & {$[28]$} & 53 \\
$\boldsymbol{\alpha 1 M}$ & Cubilin & n.d. & $\varnothing$ & 92 \\
\hline
\end{tabular}

* Calculations are based on estimated glomerular sieving coefficients of plasma proteins [32].

A

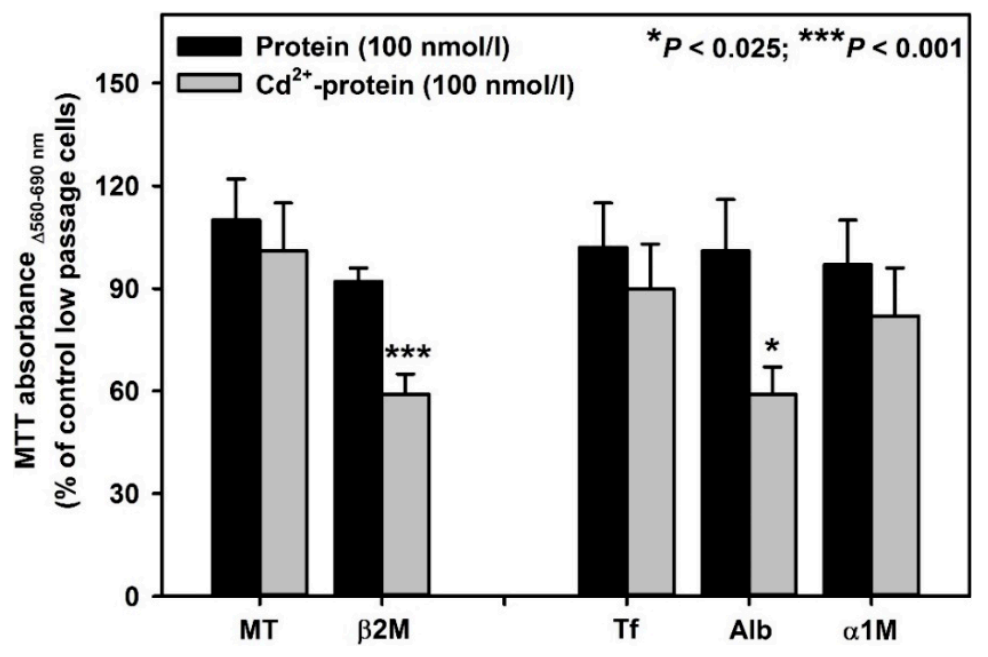

Figure 3. Cont. 


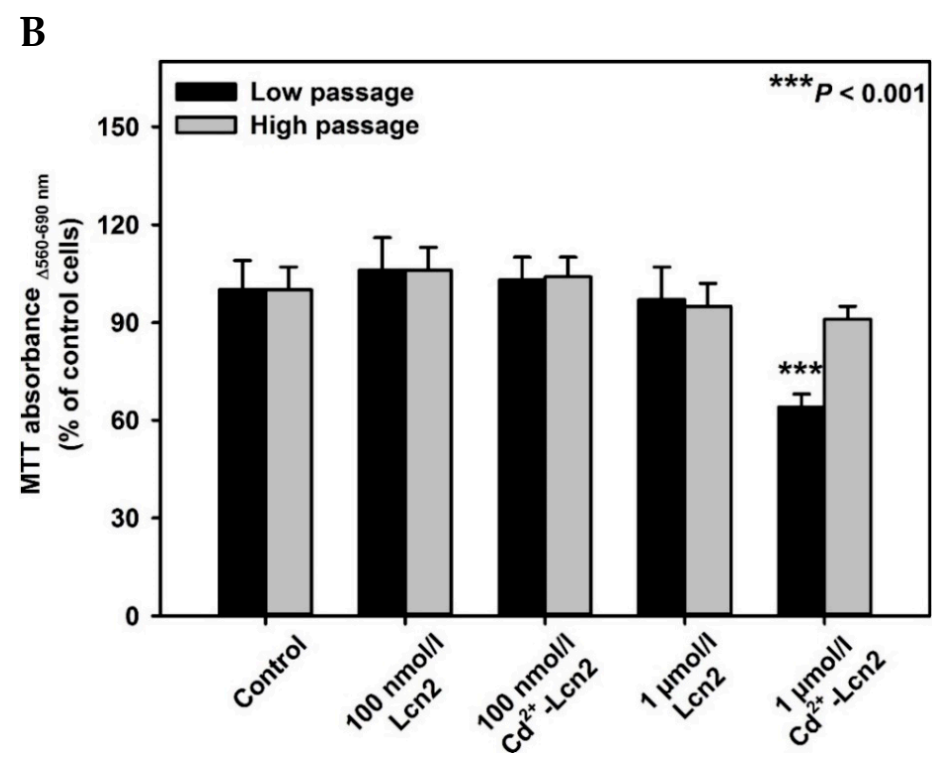

Figure 3. Relevant in vivo concentrations of $\mathrm{Cd}^{2+}$-complexes with $\beta 2$-microglobulin $(\beta 2 \mathrm{M})$, albumin (Alb) or lipocalin-2 (Lcn2), but not metallothionein (MT), increase toxicity in megalin:cubilin-expressing WKPT-0293 Cl.2. Treatments were performed in $\mathrm{SFM}_{\text {mod, }}$ and cell viability was assessed using MTT assay. (A) Low passage cells were exposed to glomerular filtrated proteins (ligands of megalin (MT, $\beta 2 \mathrm{M}$ ) or cubilin (Tf, Alb, $\alpha 1 \mathrm{M})$ ) alone or complexed to $\mathrm{Cd}^{2+}$ for $24 \mathrm{~h}$. Means \pm SEM of 4-9 experiments are shown. Absorbance values of control cells were $1.06 \pm 0.06$ a.u. $(n=31)$ and set to $100 \%$. (B) Low and high passage cells were exposed to $100 \mathrm{nmol} / \mathrm{L}$ or $1 \mu \mathrm{mol} / \mathrm{L}$ of the megalin ligand Lcn 2 or Cd ${ }^{2+}-\mathrm{Lcn} 2$ for $24 \mathrm{~h}$. The higher concentration of $1 \mu \mathrm{mol} / \mathrm{L}$ approximates in vivo concentrations of Lcn2 in the glomerular ultrafiltrate (see Table 1). Means \pm SEM of 4-6 experiments are shown. Absorbance values of control cells were $1.30 \pm 0.12$ a.u. $(n=6)$ and $1.42 \pm 0.25$ a.u. $(n=4)$ for low and high passage cells, respectively, and set to $100 \%$. Statistical analyses for pairwise comparisons were performed using unpaired $t$-test.

Alb uptake by WKPT-0293 Cl.2 cells was confirmed by fluorescence microscopy of FITC-coupled $\mathrm{Alb}$ (100 nmol/L for $24 \mathrm{~h}$ ). Interestingly, although low passage cells showed increased internalization of FITC-Alb (Figure 4), the difference to high passage cells was not as pronounced as megalin:cubilin expression (Figure 1) and toxicity in low passage cells (Figure 3A). This was also the case for $\beta 2 \mathrm{M}$ uptake.

A

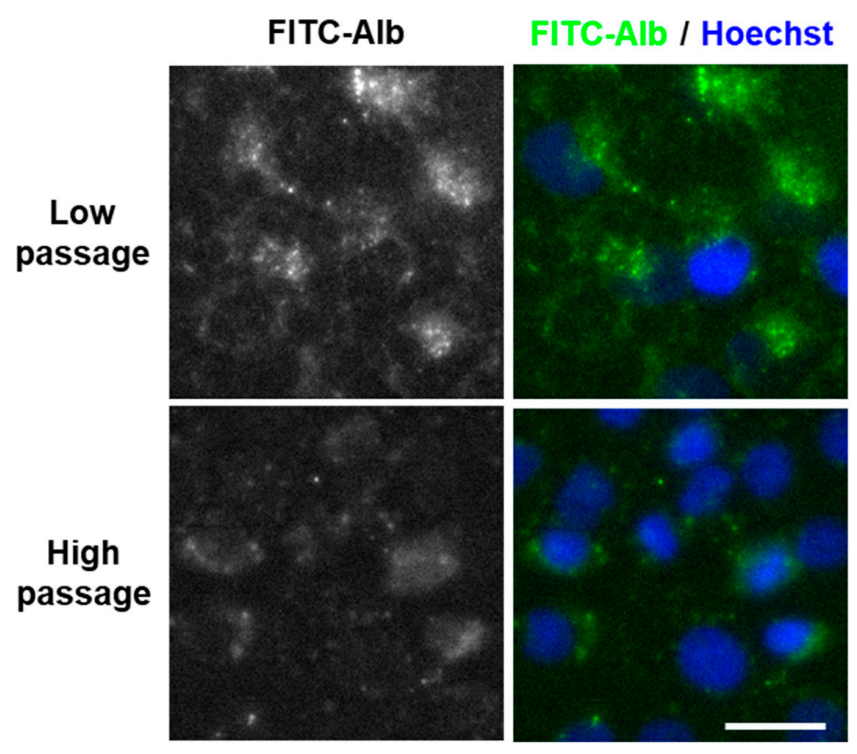

Figure 4. Cont. 
B

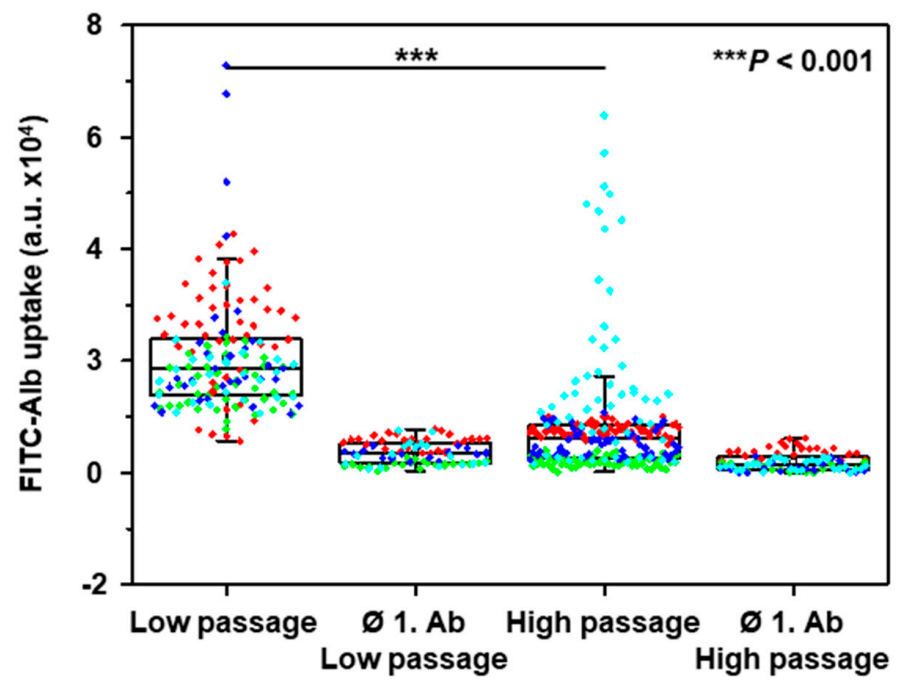

Figure 4. Uptake of FITC-albumin (Alb) in low and high passage WKPT-0293 Cl. 2 cells. (A) Cells were exposed to $100 \mathrm{nmol} / \mathrm{L} \mathrm{FITC-Alb}$ (green) in $\mathrm{SFM}_{\text {mod }}$ for $24 \mathrm{~h}$. Subsequently, cells were fixed, and mounted for fluorescence imaging. Nuclei were counterstained with Hoechst 33342 (blue). The experiment is representative of four similar ones. Scale bar $=20 \mu \mathrm{m}$. (B) Fluorescence intensity was analyzed in 83-238 cells (dots) from 4 different experiments (colors). For details of box plot statistics, see Section 4.2. Statistical analysis compared the low and high passage cells by non-parametric one-way ANOVA (Kruskal-Wallis-Test, using Dunn's post-hoc analysis.

\section{Discussion}

The current dogma of chronic $\mathrm{Cd}^{2+}$ nephrotoxicity assumes that (1) $\mathrm{Cd}^{2+}$ exposure results in initial accumulation of the metal ion in the liver, where it induces MT synthesis and binds to the protein; (2) as a result of normal cell turnover, or hepatic damage some of the $\mathrm{Cd}^{2+}-\mathrm{MT}$ is released into the blood; (3) $\mathrm{Cd}^{2+}$-MT in the circulation is rapidly cleared by the renal glomeruli and reabsorbed by the PT; (4) this translocation eventually leads to nephrotoxicity [4]. Thus MT is claimed to serve both as a storage and a transport protein for $\mathrm{Cd}^{2+}$ [33].

Yet, a thorough assessment of the literature clearly indicates that this model can no longer be accepted. Firstly, and most importantly, susceptibility of MT-null mice to chronic $\mathrm{CdCl}_{2}$-induced nephrotoxicity indicates that renal PT injury is not mediated by the $\mathrm{Cd}^{2+}-\mathrm{MT}$ complex [34]. Secondly, renal uptake of ultrafiltrated $\mathrm{Cd}^{2+}$-MT was only observed with very high concentrations of parenterally applied acute $\mathrm{Cd}^{2+}$-MT injections varying between $0.7-2 \mu \mathrm{mol} / \mathrm{L}[35-39]$ and is an inappropriate model for the study of chronic $\mathrm{Cd}^{2+}$-induced nephrotoxicity [40]. Finally, the in vivo evidence for redistribution of liver $\mathrm{Cd}^{2+}$-MT to the kidney is based on experimental models that rely on excessive hepatic $\mathrm{Cd}^{2+}$ accumulation or exposure to hepatotoxic agents $[7,41-44]$ and is not observed in mice subjected to chronic administration of $\mathrm{Cd}^{2+}$ via drinking water, which mimics chronic exposure from dietary sources [9].

Overall, in light of our reasoning and in context of a $K_{D}$ of megalin:cubilin to MT in the high micromolar range [22,23], it was reasonable to assume that other filtered $\mathrm{Cd}^{2+}$-protein complexes may at least partly mediate chronic PT toxicity. Complex formation of $\mathrm{Alb}, \beta 2 \mathrm{M}$ and $\mathrm{Tf}$ with $\mathrm{Cd}^{2+}$ and other divalent metal ions with a $K_{D}$ of around $1 \mu \mathrm{mol} / \mathrm{L}$ and maximally two $\mathrm{Cd}^{2+}$ binding sites has been described [18-20]. We also investigated Lcn2 and $\alpha 1 \mathrm{M}$ that are both filtered and ligands of megalin [31] and cubilin [29], respectively, for which no binding data to $\mathrm{Cd}^{2+}$ are available in the literature. $\mathrm{Cd}^{2+}-\beta 2 \mathrm{M}$, $\mathrm{Cd}^{2+}-\mathrm{Alb}$ and $\mathrm{Cd}^{2+}-\mathrm{Lcn} 2$ at concentrations that are compatible with the ultrafiltrated concentrations of these proteins in vivo caused toxicity of low passage WKPT-0293 Cl.2 cells expressing megalin:cubilin and were internalized by the cells. It may be debated that these proteins exhibit relatively low affinities 
to $\mathrm{Cd}^{2+}$ compared to MT, indicating that at steady-state they will be maximally saturated by $\sim 1 \%$ to form complexes with blood $\mathrm{Cd}^{2+}$ (with a concentration of $0.3-5 \mathrm{nM} \mathrm{[10])} \mathrm{whereas} \mathrm{MT} \mathrm{in} \mathrm{the} \mathrm{circulation}$ will be $\mathrm{Cd}^{2+}$-saturated (based on equivalent low nanomolar concentrations of MT and $\mathrm{Cd}^{2+}$ and a $K_{D}$ for $\left.\mathrm{Cd}^{2+} \sim 10^{-14} \mathrm{~mol} / \mathrm{L}[3]\right)$. Yet the relatively high concentrations of $\beta 2 \mathrm{M}, \mathrm{Alb}$ and $\mathrm{Lcn} 2$ in the primary filtrate compared to MT, their high binding affinity to megalin (Table 1) and the multiplicative effect of continuous glomerular filtration makes them more likely to contribute to chronic renal PT toxicity than $\mathrm{Cd}^{2+}$-MT whose concentration in the primary filtrate is at least $10^{5}$-times lower $[11,12]$ than its affinity to megalin [22]. Of note, $\beta 2 \mathrm{M}$ is known as an early urinary biomarker of renal PT toxicity induced by chronic low $\mathrm{Cd}^{2+}$ exposure, because when its reabsorption via megalin:cubilin is disrupted $[38,45,46]$ (reviewed in reference [47]), it is consequently excreted into the urine.

Strikingly, the difference in uptake of Alb and $\beta 2 \mathrm{M}$ between low and high passage cells was less pronounced than expected from the megalin:cubilin expression (Figure 1) and toxicity data, suggesting that other entry pathways for these $\left(\mathrm{Cd}^{2+}\right)$ protein complexes could contribute to endocytosis without leading to toxicity, such as transcytosis [48].

From the current data $\mathrm{Cd}^{2+}$-MT is unlikely to be endocytosed in the PT, and because only $0.02-03 \%$ of filtered proteins, including MT, are excreted with the urine, [49] more distal nephron segments must be involved in MT retrieval. Indeed, the renal medulla accumulates significant amounts of both $\mathrm{Cd}^{2+}$ and $\mathrm{Cd}^{2+}$-MT in humans, and concentrations of both $\mathrm{Cd}^{2+}$ compounds can reach $\sim 50 \%$ of the levels found in the cortex [50,51]. MT was detected by immunohistochemistry in distal nephron segments of rodent and human kidney [52-54], and the expression of MT was induced by exposure to $\mathrm{Cd}^{2+}[53,54]$. A high-affinity receptor for MT has been identified in the distal nephron, the Lcn2 receptor (Lcn2-R/SLC22a17/BOCT [brain organic cation transporter]). Lcn2-R is expressed apically in the distal convoluted tubule (DCT) and collecting duct (CD), mainly inner medullary [55]. Chinese hamster ovary cells transiently expressing Lcn2-R and cultured mouse DCT cell line endogenously expressing Lcn2-R internalized sub-micromolar concentrations of fluorescence-labelled MT $\left(K_{D} \sim 100 \mathrm{nmol} / \mathrm{L}\right)$, $\mathrm{Tf}$ or Alb whose uptake was prevented by picomolar Lcn 2 concentrations, which indicated that the Lcn2-R mediates uptake of these proteins [55]. Exposure of both cell lines expressing Lcn2-R to $700 \mathrm{nM} \mathrm{Cd}^{2+}$-MT induced cell death that could be reduced by Lcn2 [55], which indicates that $\mathrm{Cd}^{2+}$-MT is a high-affinity ligand of Lcn2-R that mediates endocytosis and toxicity of $\mathrm{Cd}^{2+}-\mathrm{MT}$ in the distal nephron. Hence, although $\mathrm{Cd}^{2+}$-MT may not be directly involved in $\mathrm{Cd}^{2+}$-induced PT damage, it is likely responsible for renal DCT/CD/medulla $\mathrm{Cd}^{2+}$ uptake and toxicity. Considering that up to $90 \%$ of the primary renal fluid is reabsorbed by the PT and Henle loop and about $1 \%$ is excreted as urine (reviewed in references $[56,57]$ ), luminal $\mathrm{Cd}^{2+}-\mathrm{MT}$ concentrations in the distal nephron may increase up to $500 \mathrm{nmol} / \mathrm{L}$ (cf. [11,12]), which is in the range of the binding affinity of the Lcn2-R for MT [55]. Investigation of distal nephron damage has been neglected so far, and only rare evidence for chronic $\mathrm{Cd}^{2+}$ toxicity of the distal portions of the nephron has been obtained, both in experimental animals [58,59] and $\mathrm{Cd}^{2+}$-exposed workers [60].

In summary, at relevant concentrations present in the primary filtrate, renal PT cells do not succumb to $\mathrm{Cd}^{2+}$ toxicity by $\mathrm{Cd}^{2+}$-MT uptake. Rather, megalin:cubilin endocytosis of other $\mathrm{Cd}^{2+}$-complexed ligands, namely $\mathrm{Cd}^{2+}-\beta 2 \mathrm{M}, \mathrm{Cd}^{2+}-\mathrm{Alb}$ and/or $\mathrm{Cd}^{2+}-\mathrm{Lcn} 2$, damages the PT.

\section{Materials and Methods}

\subsection{Materials}

Metallothionein-1 (MT) was obtained from Enzo Life Sciences, Lörrach, Germany (cat. \# ALX-202072-M001). ß2-microglobulin ( $\beta 2 \mathrm{M}$, cat. \# M4890), apo-transferrin (Tf, cat. \# T2252), albumin (Alb, cat. \# A6414), Chelex 100 (cat. \# C7901) and 2,3-dihydroxybenzoic acid (DHBA; cat. \# 126209) were obtained from Sigma-Aldrich, Taufkirchen, Germany. $\alpha 1$-microglobulin ( $\alpha 1 \mathrm{M}$, cat. \# ab96149) was purchased from Abcam, Berlin, Germany. Recombinant mouse NGAL/lipocalin-2 (Lcn2) (cat. \# 1857-LC) was from R\&D Systems, Abingdon, United Kingdom. All protein ligands had a purity of $\geq 95 \%-99 \%$ according 
to the suppliers, were lyophilized proteins and reconstituted in phosphate buffered saline (PBS). All other chemicals were from commercial sources and of analytical grade.

\subsection{Methods}

\subsubsection{Cell Culture}

An immortalized cell line from the S1 segment of rat PT (WKPT-0293 Cl.2) [24] was cultured in serum-containing medium (SCM), essentially as previously described [61] with the addition of $2.5 \mu \mathrm{g} / \mathrm{mL}$ plasmocin (InvivoGen, Toulouse, France) in $25 \mathrm{~cm}^{2}$ standard tissue culture flasks (Sarstedt, Nümbrecht, Germany) at $37{ }^{\circ} \mathrm{C}$ in a humidified incubator with $5 \% \mathrm{CO}_{2}$. Cells were passaged twice a week upon reaching confluency. Low passage cells are defined as p31-40 and high passage cells as $p>100$.

\subsubsection{Coupling of $\mathrm{Cd}^{2+}$-Protein Complexes}

$\mathrm{Cd}^{2+}$-coupled proteins (MT, Tf, Alb, $\beta 2 \mathrm{M}, \alpha 1 \mathrm{M}$ ) were prepared exactly, as described previously [62], by mixing protein solutions with a 10 -fold molar excess of $\mathrm{CdCl}_{2}$ solution. Briefly, $\mathrm{MT}(1 \mathrm{mmol} / \mathrm{L}$ in $10 \mathrm{mmol} / \mathrm{L}$ Tris/ $\mathrm{HCl} \mathrm{pH}$ 7.4) was mixed 1:1 with $10 \mathrm{mmol} / \mathrm{L} \mathrm{CdCl}_{2}$ solution, unbound metal ions were removed with a 2:1 excess of Chelex 100 followed by centrifugation. The resulting supernatant was retained and contained $0.5 \mathrm{mmol} / \mathrm{L} \mathrm{MT}$ complexed to $3.5 \mathrm{mmol} / \mathrm{L} \mathrm{Cd}^{2+}$, assuming $7 \mathrm{Cd}^{2+}$ ions per molecule of MT [3]. Tf, Alb, $\beta 2 \mathrm{M}$ or $\alpha 1 \mathrm{M}(0.1 \mathrm{mmol} / \mathrm{L})$ were complexed accordingly using a $1 \mathrm{mmol} / \mathrm{L}$ $\mathrm{CdCl}_{2}$ solution.

For complexation of Lcn 2 with $\mathrm{CdCl}_{2}, 0.5 \mathrm{mmol} / \mathrm{L} \mathrm{DHBA}$ (in $100 \mathrm{mmol} / \mathrm{L} \mathrm{Tris} / \mathrm{HCl}, \mathrm{pH} 8.0$ ) and $5 \mathrm{mmol} / \mathrm{L} \mathrm{CdCl}_{2}$ solutions were mixed 1:1 at RT for $1 \mathrm{~h}$. The mixture was diluted 1:1 with $50 \mu \mathrm{mol} / \mathrm{L}$ Lcn2 dissolved in PBS and stirred for an additional hour. Unbound $\mathrm{Cd}^{2+}$ was removed with Chelex 100 , as described above.

\subsubsection{Cell Viability Assay of WKPT-0293 Cl.2 Cells}

To compensate for different cell doubling times, $12.5 \times 10^{3}$ low-passage or $7.5 \times 10^{3}$ high-passage WKPT-0293 Cl. 2 cells were seeded per well in 24-well plates and cultured for $24 \mathrm{~h}$ to obtain $\sim 30-50 \%$ confluence. Cells were then exposed to proteins or $\mathrm{Cd}^{2+}$-complexed proteins in modified serum-free medium (SFM mod; DMEM/F12, $1.2 \mathrm{mg} / \mathrm{mL} \mathrm{NaHCO}_{3}, 100 \mathrm{U} / \mathrm{mL}$ penicillin $\mathrm{G}, 100 \mu \mathrm{g} / \mathrm{mL}$ streptomycin sulfate, $4 \mu \mathrm{g} / \mathrm{mL}$ dexamethasone) for $24 \mathrm{~h}$. After treatments, cell viability was determined by the MTT assay, as previously described [61].

\subsubsection{Quantitative Real-Time Polymerase Chain Reaction (qPCR)}

Total RNA was isolated from confluent WKPT-0293 Cl.2 cells using High Pure RNA Isolation Kit (Roche) according to the manufacturer's instructions and $1 \mu \mathrm{g}$ of total RNA was reverse transcribed into cDNA using First Strand cDNA Synthesis Kit (Thermo Scientific, Schwerte, Germany). Quantitative real-time PCR was carried out using Takyon Rox SYBR MasterMix dTTP Blue (Eurogentec, Cologne, Germany) on a StepOnePlus cycler (Applied Biosystems, Schwerte, Germany). The cycling conditions were $3 \mathrm{~min}$ at $95^{\circ} \mathrm{C}$, followed by 40 cycles of $10 \mathrm{~s}$ at $95^{\circ} \mathrm{C}$ and $30 \mathrm{~s}$ at $60^{\circ} \mathrm{C}$. Primer sequences are given in Table 2. Gapdh was used as a housekeeping gene. For analysis of relative changes, data was analyzed according to the $\Delta \Delta \mathrm{C}_{\mathrm{T}}$ method [63].

Table 2. qPCR primers.

\begin{tabular}{lcc}
\hline \multicolumn{1}{c}{ Gene } & Forward Primer $\left(\mathbf{5}^{\prime} \mathbf{- \mathbf { 3 } ^ { \prime } \mathbf { \prime } )}\right.$ & Reverse Primer $\left(\mathbf{5}^{\prime} \mathbf{- 3}^{\prime} \mathbf{)}\right.$ \\
\hline Rat megalin/Lrp2 (NM_030827.1) $^{\text {a }}$ & TGGAATCTCCCTTGATCCTG & TGTTGCTGCCATCAGTCTTC \\
$\begin{array}{l}\text { Rat cubilin/Cubn (NM_053332) } \\
\text { Rat Gapdh (NM_017008) }\end{array}$ & GCACTGGCAATGAACTAGCA & TGATCCAGGAGCACTCTGTG \\
\hline
\end{tabular}

a Primer sequences taken from Prabakaran et al. [64]. 


\subsubsection{Immunofluorescence Staining of Megalin}

Low and high passage WKPT-0293 Cl.2 cells were grown on coverslips until they reached $\sim 80 \%$ confluence. Immunofluorescence of megalin staining was performed as described previously [16]. Briefly, cells were fixed in $4 \%$ paraformaldehyde/PBS, permeabilized with $0.1 \%$ Triton X-100/PBS, blocked in 1\% bovine serum albumin/PBS, incubated with primary mouse LRP2 antibody (1:200, cat. \# NB110-96417, Novus Biologicals, Wiesbaden, Germany) followed by secondary donkey anti-mouse antibody conjugated to Alexa488 (1:500 cat. \# 715-545-202, Dianova, Hamburg, Germany) together with the nuclear dye Hoechst $33342(0.8 \mu \mathrm{g} / \mathrm{mL})$. Coverslips were mounted onto glass slides with DAKO fluorescence mounting medium.

\subsubsection{Immunoblotting}

SDS-PAGE and immunodetection of cubilin were performed essentially as described elsewhere [23]. For detection of $\beta$-actin, protein samples were separated by $10 \%$ SDS-PAGE. Antibodies: sheep anti-cubilin (cat. \# AF3700, R\&D Systems, Abingdon, United Kingdom), $1.0 \mu \mathrm{g} / \mathrm{mL}$; mouse anti- $\beta$-actin (cat. \# A5316, Sigma-Aldrich, Taufkirchen, Germany), 1:20,000.

\subsubsection{Detection of Alb and $\beta 2 \mathrm{M}$ Uptake}

Low and high passage WKPT- $0293 \mathrm{Cl} .2$ cells on coverslips ( $\sim 50 \%$ confluence) were incubated with $100 \mathrm{nmol} / \mathrm{L}$ FITC-labeled Alb (cat. \# A23015, Thermo Scientific, Schwerte, Germany) or $100 \mathrm{nmol} / \mathrm{L}$ ß2M (cat. \# ab175031, Abcam, Berlin, Germany) in SFM mod for $24 \mathrm{~h}$. Subsequently, cells were washed and fixed as described above. Alb treated cells were mounted without additional immunostaining. $\beta 2 \mathrm{M}$ exposed cells were permeabilized and stained according to the above described protocol, using a primary $\beta 2 \mathrm{M}$ antibody (1:500, cat. \# ab175031, Abcam, Berlin, Germany) and secondary goat anti-rabbit antibody conjugated to Alexa488 (1:500, cat. \# A-11008, Invitrogen, Schwerte, Germany).

\subsubsection{Fluorescence Imaging}

Cell were imaged on a Zeiss Axiovert 200M equipped with an Fluar 40x, 1.3 NA oil immersion objective (Zeiss, Oberkochen, Germany), a CoolSnap ES camera (Roper Scientific, Planegg, Germany) and a Sola SM II light engine (Lumencor, Tübingen, Germany) using Visiview imaging software (V 3.3.0.6, Visitron Systems GmbH, Puchheim, Germany). 3-6 representative areas on each coverslip were chosen for acquisition of brightfield images and whole cell z-stacks with a step size of $800 \mathrm{~nm}$ for fluorescent labels. Images were analyzed and quantified using Fiji [65]. To this end, regions of interest (ROI) were drawn around each cell from which background was subtracted. The z-stack slice with the highest mean intensity for each ROI was selected for further analysis.

\subsubsection{Statistics}

Unless otherwise indicated, the experiments were repeated at least three times with independent cultures. Bar diagrams showing means \pm SEM are used for parametric data sets, unless otherwise indicated. Figures with non-parametric data are shown as box and whisker plots, presenting 25 and 75 percentiles, mean values (square symbol), median (horizontal line) and $1.5 \times$ outliers (whiskers). Scatter plots show single data points of color-coded repetitions. Statistical comparison between 2 groups was performed using Student's unpaired t-test or Mann-Whitney-test in cases of parametric or nonparametric distribution, respectively. If more than two conditions were compared, either one-way ANOVA with Bonferroni post-hoc test (parametric) or Kruskal-Wallis with subsequent Dunn's post-hoc test were applied using Graph-Pad Prism, San Diego, CA, USA. When one group within a specific data set showed a non-parametric distribution, the whole data set was considered as non-parametric. Results with $p<0.05$ were considered to be statistically significant. 
Author Contributions: Conceptualization, F.T.; Methodology, J.F., B.S., R.Z., I.P.Z.G. and W.-K.L.; Validation, J.F., R.Z., W.-K.L. and F.T.; Formal analysis, J.F., B.S., R.Z., I.P.Z.G. and W.-K.L.; Investigation, J.F., R.Z. and W.-K.L.; Writing—original draft preparation, J.F., B.S., R.Z., W.-K.L. and F.T.; Writing—review and editing, J.F., B.S., R.Z., W.-K.L., O.C.B. and F.T.; Visualization, J.F. and F.T.; Supervision, W.-K.L., O.C.B. and F.T.; Project administration, F.T. and O.C.B.; Funding acquisition, F.T. and O.C.B.

Funding: This research is funded by a collaborative grant Conacyt-BMBF (BMBF \# 01DN16039; Conacyt \# 267755) between research groups in Germany (J.F., B.S., R.Z., W.-K.L. and F.T.) and Mexico (I.P.Z.G. and O.C.B.), the DFG (TH345; F.T.), Intramural Research Funding Program at Witten/Herdecke University (IFF2018-52; W.-K.L.), and ZBAF (F.T.).

Conflicts of Interest: The authors declare no conflict of interest. The funders had no role in the design of the study; in the collection, analyses, or interpretation of data; in the writing of the manuscript, or in the decision to publish the results.

\section{References}

1. World Health Organization (WHO). Exposure to Cadmium: A Major Public Health Concern. 2010. Available online: https://www.who.int/ipcs/assessment/public_health/cadmium/en/ (accessed on 1 March 2019).

2. Thévenod, F.; Lee, W.K. Toxicology of cadmium and its damage to mammalian organs. Metal. Ions Life Sci. 2013, 11, 415-490.

3. Freisinger, E.; Vasak, M. Cadmium in metallothioneins. Met. Ions Life Sci. 2013, 11, 339-371.

4. Liu, J.; Goyer, R.A.; Waalkes, M.P. Toxic effects of metals. In Casarett \& Doull's Toxicology: The Basic Science of Poisons, 7th ed.; Klaasen, C.D., Ed.; McGraw -Hill: New York, NY, USA, 2008; pp. 931-979.

5. Sabolic, I.; Breljak, D.; Skarica, M.; Herak-Kramberger, C.M. Role of metallothionein in cadmium traffic and toxicity in kidneys and other mammalian organs. Biometals 2010, 23, 897-926. [CrossRef] [PubMed]

6. Nordberg, M.; Nordberg, G.F. Distribution of metallothionein-bound cadmium and cadmium chloride in mice: Preliminary studies. Environ. Health Perspect. 1975, 12, 103-108. [CrossRef] [PubMed]

7. Dudley, R.E.; Gammal, L.M.; Klaassen, C.D. Cadmium-induced hepatic and renal injury in chronically exposed rats: Likely role of hepatic cadmium-metallothionein in nephrotoxicity. Toxicol Appl. Pharmacol. 1985, 77, 414-426. [CrossRef]

8. Nomiyama, K.; Nomiyama, H.; Kameda, N. Plasma cadmium-metallothionein, a biological exposure index for cadmium-induced renal dysfunction, based on the mechanism of its action. Toxicology 1998, 129, 157-168. [CrossRef]

9. Thijssen, S.; Maringwa, J.; Faes, C.; Lambrichts, I.; Van Kerkhove, E. Chronic exposure of mice to environmentally relevant, low doses of cadmium leads to early renal damage, not predicted by blood or urine cadmium levels. Toxicology 2007, 229, 145-156. [CrossRef] [PubMed]

10. Klotz, K.; Weistenhofer, W.; Drexler, H. Determination of cadmium in biological samples. Met. Ions Life Sci. 2013, 11, 85-98. [PubMed]

11. Milnerowicz, H.; Bizon, A. Determination of metallothionein in biological fluids using enzyme-linked immunoassay with commercial antibody. Acta Biochim. Pol. 2010, 57, 99-104. [CrossRef]

12. Akintola, D.F.; Sampson, B.; Fleck, A. Development of an enzyme-linked immunosorbent assay for human metallothionein-1 in plasma and urine. J. Lab. Clin. Med. 1995, 126, 119-127. [PubMed]

13. Thévenod, F. Nephrotoxicity and the proximal tubule. Insights from cadmium. Nephron Physiol. 2003, 93, 87-93. [CrossRef]

14. Schuh, C.D.; Polesel, M.; Platonova, E.; Haenni, D.; Gassama, A.; Tokonami, N.; Ghazi, S.; Bugarski, M.; Devuyst, O.; Ziegler, U.; et al. Combined structural and functional imaging of the kidney reveals major axial differences in proximal tubule endocytosis. J. Am. Soc. Nephrol. 2018, 29, 2696-2712. [CrossRef]

15. Christensen, E.I.; Birn, H.; Storm, T.; Weyer, K.; Nielsen, R. Endocytic receptors in the renal proximal tubule. Physiology 2012, 27, 223-236. [CrossRef] [PubMed]

16. Abouhamed, M.; Wolff, N.A.; Lee, W.K.; Smith, C.P.; Thévenod, F. Knockdown of endosomal/lysosomal divalent metal transporter 1 by rna interference prevents cadmium-metallothionein-1 cytotoxicity in renal proximal tubule cells. Am. J. Physiol. Renal Physiol. 2007, 293, F705-F712. [CrossRef]

17. Thévenod, F.; Wolff, N.A. Iron transport in the kidney: Implications for physiology and cadmium nephrotoxicity. Met. Integr. Biometal Sci. 2016, 8, 17-42. [CrossRef] 
18. Harris, W.R.; Madsen, L.J. Equilibrium studies on the binding of cadmium(ii) to human serum transferrin. Biochemistry 1988, 27, 284-288. [CrossRef]

19. Goumakos, W.; Laussac, J.P.; Sarkar, B. Binding of cadmium(ii) and zinc(ii) to human and dog serum albumins. An equilibrium dialysis and 113cd-nmr study. Biochem. Cell Biol. 1991, 69, 809-820. [CrossRef]

20. Eakin, C.M.; Knight, J.D.; Morgan, C.J.; Gelfand, M.A.; Miranker, A.D. Formation of a copper specific binding site in non-native states of beta-2-microglobulin. Biochemistry 2002, 41, 10646-10656. [CrossRef] [PubMed]

21. Christensen, E.I.; Birn, H. Megalin and cubilin: Synergistic endocytic receptors in renal proximal tubule. Am. J. Physiol. Renal Physiol. 2001, 280, F562-F573. [CrossRef]

22. Klassen, R.B.; Crenshaw, K.; Kozyraki, R.; Verroust, P.J.; Tio, L.; Atrian, S.; Allen, P.L.; Hammond, T.G. Megalin mediates renal uptake of heavy metal metallothionein complexes. Am. J. Physiol. Renal Physiol. 2004, 287, F393-F403. [CrossRef] [PubMed]

23. Wolff, N.A.; Abouhamed, M.; Verroust, P.J.; Thévenod, F. Megalin-dependent internalization of cadmiummetallothionein and cytotoxicity in cultured renal proximal tubule cells. J. Pharmacol. Exp. Ther. 2006, 318, 782-791. [CrossRef]

24. Woost, P.G.; Orosz, D.E.; Jin, W.; Frisa, P.S.; Jacobberger, J.W.; Douglas, J.G.; Hopfer, U. Immortalization and characterization of proximal tubule cells derived from kidneys of spontaneously hypertensive and normotensive rats. Kidney Int. 1996, 50, 125-134. [CrossRef]

25. Nielsen, R.; Birn, H.; Moestrup, S.K.; Nielsen, M.; Verroust, P.; Christensen, E.I. Characterization of a kidney proximal tubule cell line, llc-pk1, expressing endocytotic active megalin. J. Am. Soc. Nephrol. 1998, 9, 1767-1776. [PubMed]

26. Zhai, X.Y.; Nielsen, R.; Birn, H.; Drumm, K.; Mildenberger, S.; Freudinger, R.; Moestrup, S.K.; Verroust, P.J.; Christensen, E.I.; Gekle, M. Cubilin- and megalin-mediated uptake of albumin in cultured proximal tubule cells of opossum kidney. Kidney Int. 2000, 58, 1523-1533. [CrossRef] [PubMed]

27. Kozyraki, R.; Fyfe, J.; Verroust, P.J.; Jacobsen, C.; Dautry-Varsat, A.; Gburek, J.; Willnow, T.E.; Christensen, E.I.; Moestrup, S.K. Megalin-dependent cubilin-mediated endocytosis is a major pathway for the apical uptake of transferrin in polarized epithelia. Proc. Natl. Acad. Sci. USA 2001, 98, 12491-12496. [CrossRef]

28. Birn, H.; Fyfe, J.C.; Jacobsen, C.; Mounier, F.; Verroust, P.J.; Orskov, H.; Willnow, T.E.; Moestrup, S.K.; Christensen, E.I. Cubilin is an albumin binding protein important for renal tubular albumin reabsorption. J. Clin. Invest. 2000, 105, 1353-1361. [CrossRef] [PubMed]

29. Storm, T.; Emma, F.; Verroust, P.J.; Hertz, J.M.; Nielsen, R.; Christensen, E.I. A patient with cubilin deficiency. N. Engl. J. Med. 2011, 364, 89-91. [CrossRef] [PubMed]

30. Leheste, J.R.; Rolinski, B.; Vorum, H.; Hilpert, J.; Nykjaer, A.; Jacobsen, C.; Aucouturier, P.; Moskaug, J.O.; Otto, A.; Christensen, E.I.; et al. Megalin knockout mice as an animal model of low molecular weight proteinuria. Am. J. Pathol. 1999, 155, 1361-1370. [CrossRef]

31. Hvidberg, V.; Jacobsen, C.; Strong, R.K.; Cowland, J.B.; Moestrup, S.K.; Borregaard, N. The endocytic receptor megalin binds the iron transporting neutrophil-gelatinase-associated lipocalin with high affinity and mediates its cellular uptake. FEBS Lett. 2005, 579, 773-777. [CrossRef]

32. Norden, A.G.; Lapsley, M.; Lee, P.J.; Pusey, C.D.; Scheinman, S.J.; Tam, F.W.; Thakker, R.V.; Unwin, R.J.; Wrong, O. Glomerular protein sieving and implications for renal failure in fanconi syndrome. Kidney Int. 2001, 60, 1885-1892. [CrossRef]

33. Shaikh, Z.A. Metallothionein as a storage protein for cadmium: Its toxicological implications. Dev. Toxicol. Environ. Sci. 1982, 9, 69-76.

34. Liu, J.; Liu, Y.; Habeebu, S.S.; Klaassen, C.D. Susceptibility of mt-null mice to chronic cdcl2-induced nephrotoxicity indicates that renal injury is not mediated by the cdmt complex. Toxicol. Sci. 1998, 46, 197-203.

35. Cherian, M.G.; Shaikh, Z.A. Metabolism of intravenously injected cadmium-binding protein. Biochem. Biophys. Res. Commun. 1975, 65, 863-869. [CrossRef]

36. Cherian, M.G.; Goyer, R.A.; Delaquerriere-Richardson, L. Cadmium-metallothionein-induced nephropathy. Toxicol. Appl. Pharmacol. 1976, 38, 399-408.

37. Foulkes, E.C. Renal tubular transport of cadmium-metallothionein. Toxicol. Appl. Pharmacol. 1978, 45, 505-512. [CrossRef]

38. Bernard, A.M.; Ouled Amor, A.; Lauwerys, R.R. The effects of low doses of cadmium-metallothionein on the renal uptake of beta 2-microglobulin in rats. Toxicol. Appl. Pharmacol. 1987, 87, 440-445. [CrossRef] 
39. Tang, W.; Shaikh, Z.A. Renal cortical mitochondrial dysfunction upon cadmium metallothionein administration to sprague-dawley rats. J. Toxicol. Environ. Health A 2001, 63, 221-235. [CrossRef] [PubMed]

40. Liu, J.; Habeebu, S.S.; Liu, Y.; Klaassen, C.D. Acute cdmt injection is not a good model to study chronic cd nephropathy: Comparison of chronic cdcl 2 and cdmt exposure with acute cdmt injection in rats. Toxicol. Appl. Pharmacol. 1998, 153, 48-58. [CrossRef] [PubMed]

41. Cain, K.; Griffiths, B. Transfer of liver cadmium to the kidney after aflatoxin induced liver damage. Biochem. Pharmacol. 1980, 29, 1852-1855. [CrossRef]

42. Tanaka, K.; Nomura, H.; Onosaka, S.; Min, K. Release of hepatic cadmium by carbon tetrachloride treatment. Toxicol. Appl. Pharmacol. 1981, 59, 535-539. [CrossRef]

43. Tanaka, K. Effects of hepatic disorder on the fate of cadmium in rats. Dev. Toxicol. Environ. Sci. 1982, 9, $237-249$.

44. Chan, H.M.; Zhu, L.F.; Zhong, R.; Grant, D.; Goyer, R.A.; Cherian, M.G. Nephrotoxicity in rats following liver transplantation from cadmium-exposed rats. Toxicol. Appl. Pharmacol. 1993, 123, 89-96. [CrossRef] [PubMed]

45. Bernard, A.; Buchet, J.P.; Roels, H.; Masson, P.; Lauwerys, R. Renal excretion of proteins and enzymes in workers exposed to cadmium. Eur. J. Clin. Invest. 1979, 9, 11-22. [CrossRef] [PubMed]

46. Bernard, A.; Viau, C.; Lauwerys, R. Renal handling of human beta 2-microglobulin in normal and cadmiumpoisoned rats. Arch. Toxicol. 1983, 53, 49-57. [CrossRef] [PubMed]

47. Prozialeck, W.C.; Edwards, J.R. Early biomarkers of cadmium exposure and nephrotoxicity. Biometals 2010, 23, 793-809. [CrossRef] [PubMed]

48. Dickson, L.E.; Wagner, M.C.; Sandoval, R.M.; Molitoris, B.A. The proximal tubule and albuminuria: Really! J. Am. Soc. Nephrol. 2014, 25, 443-453. [CrossRef]

49. Norden, A.G.; Sharratt, P.; Cutillas, P.R.; Cramer, R.; Gardner, S.C.; Unwin, R.J. Quantitative amino acid and proteomic analysis: Very low excretion of polypeptides $>750$ da in normal urine. Kidney Int. 2004, 66, 1994-2003. [CrossRef]

50. Torra, M.; To-Figueras, J.; Brunet, M.; Rodamilans, M.; Corbella, J. Total and metallothionein-bound cadmium in the liver and the kidney of a population in barcelona (spain). Bull. Environ. Contam. Toxicol. 1994, 53, 509-515. [CrossRef]

51. Yoshida, M.; Ohta, H.; Yamauchi, Y.; Seki, Y.; Sagi, M.; Yamazaki, K.; Sumi, Y. Age-dependent changes in metallothionein levels in liver and kidney of the japanese. Biol. Trace Elem. Res. 1998, 63, 167-175. [CrossRef]

52. Garrett, S.H.; Sens, M.A.; Todd, J.H.; Somji, S.; Sens, D.A. Expression of mt-3 protein in the human kidney. Toxicol. Lett. 1999, 105, 207-214. [CrossRef]

53. Nagamine, T.; Nakazato, K.; Suzuki, K.; Kusakabe, T.; Sakai, T.; Oikawa, M.; Satoh, T.; Kamiya, T.; Arakawa, K. Analysis of tissue cadmium distribution in chronic cadmium-exposed mice using in-air micro-pixe. Biol. Trace Elem. Res. 2007, 117, 115-126. [CrossRef]

54. Wang, L.; Chen, D.; Wang, H.; Liu, Z. Effects of lead and/or cadmium on the expression of metallothionein in the kidney of rats. Biol. Trace Elem. Res. 2009, 129, 190-199. [CrossRef]

55. Langelueddecke, C.; Roussa, E.; Fenton, R.A.; Wolff, N.A.; Lee, W.K.; Thévenod, F. Lipocalin-2 (24p3/neutrophil gelatinase-associated lipocalin (ngal)) receptor is expressed in distal nephron and mediates protein endocytosis. J. Biol. Chem. 2012, 287, 159-169. [CrossRef]

56. Smith, H.W. The fate of sodium and water in the renal tubules. Bull. N. Y. Acad. Med. 1959, 35, $293-316$.

57. Ullrich, K.J. Niere. In Kurzgefaßtes Lehrbuch der Physiologie; Keidel, W.D., Ed.; Georg Thieme Verlag: Stuttgart, Germany, 1975.

58. Girolami, J.P.; Bascands, J.L.; Pecher, C.; Cabos, G.; Moatti, J.P.; Mercier, J.F.; Haguenoer, J.M.; Manuel, Y. Renal kallikrein excretion as a distal nephrotoxicity marker during cadmium exposure in rats. Toxicology 1989, 55, 117-129. [CrossRef]

59. Oner, G.; Senturk, U.K.; Izgut-Uysal, N. The role of cadmium in the peroxidative response of kidney to stress. Biol. Trace Elem. Res. 1995, 48, 111-117. [CrossRef]

60. Lauwerys, R.; Bernard, A. Preclinical detection of nephrotoxicity: Description of the tests and appraisal of their health significance. Toxicol. Lett. 1989, 46, 13-29. [CrossRef]

61. Lee, W.K.; Bork, U.; Gholamrezaei, F.; Thévenod, F. Cd(2+)-induced cytochrome c release in apoptotic proximal tubule cells: Role of mitochondrial permeability transition pore and ca(2+) uniporter. Am. J. Physiol. Renal Physiol. 2005, 288, F27-F39. [CrossRef] 
62. Erfurt, C.; Roussa, E.; Thevenod, F. Apoptosis by cd2+ or cdmt in proximal tubule cells: Different uptake routes and permissive role of endo/lysosomal cdmt uptake. Am. J. Physiol. Cell Physiol. 2003, 285, C1367-C1376. [CrossRef]

63. Livak, K.J.; Schmittgen, T.D. Analysis of relative gene expression data using real-time quantitative pcr and the 2(-delta delta $\mathrm{c}(\mathrm{t}))$ method. Methods 2001, 25, 402-408. [CrossRef]

64. Prabakaran, T.; Christensen, E.I.; Nielsen, R.; Verroust, P.J. Cubilin is expressed in rat and human glomerular podocytes. Nephrol. Dial. Transplant. 2012, 27, 3156-3159. [CrossRef] [PubMed]

65. Abramoff, M.D.; Magalhães, P.J.; Ram, S.J. Image processing with imagej. Biophotonics Int. 2004, 11, 36-42.

(C) 2019 by the authors. Licensee MDPI, Basel, Switzerland. This article is an open access article distributed under the terms and conditions of the Creative Commons Attribution (CC BY) license (http://creativecommons.org/licenses/by/4.0/). 